\section{PENGUATAN PELAKSANAAN PENERTIBAN PEMANFAATAN RUANG PASCA TERBITNYA UNDANG-UNDANG CIPTA KERJA}

\author{
Sutaryono Sutaryono ${ }^{1 *}$, Arsan Nurrokhman², Novita Dian \\ Lestari $^{1}$ \\ ${ }^{1}$ Sekolah Tinggi Pertanahan Nasional \\ Jl Tata Bumi No. 5, Gamping, Sleman, Yogyakarta, Indonesia \\ ${ }^{2}$ Pusat Pengembangan dan Standarisasi Kebijakan Kementerian \\ ATR/BPN, Indonesia
}

Jurnal Pengembangan Kota (2021) Volume 9 No. 2 (154-165) Tersedia online di: http://ejournal2.undip.ac.id/index.php/jpk DOI: 10.14710/jpk.9.2.154-165

\begin{abstract}
Abstrak. Pelaksanaan penegakan hukum/penertiban pemanfaatan ruang saat ini memiliki kecenderungan berhenti pada temuan adanya indikasi pelanggaran pemanfaatan ruang. Pengenaan sanksi yang merupakan hasil rekomendasi audit tata ruang masih jarang dilaksanakan. Hal tersebut memperlihatkan bahwa penegakan hukum di bidang penataan ruang masih belum optimal. Di sisi lain, muncul tantangan baru pelaksanaan penertiban pemanfaatan ruang pasca penetapan Undang-Undang Cipta Kerja (UUCK) di tahun 2020. Penelitian ini bertujuan untuk menemukenali permasalahan pelaksanaan penertiban pemanfaatan ruang untuk kemudian merumuskan strategi penguatan pelaksanaan penertiban pemanfaatan ruang pasca ditetapkannya UUCK. Penelitian dilakukan dengan menggunakan metode desk study yang mengutamakan content analysis. Content analysis dilakukan terhadap regulasi penertiban pemanfaatan ruang dan salah satu laporan hasil audit tata ruang. Data yang dikumpulkan berupa data indikasi pelanggaran pemanfaatan ruang dari hasil audit dan pelaksanaan tindaklanjutnya. Hasil penelitian menunjukkan bahwa pelaksanaan penertiban pemanfaatan ruang tidak efektif. Ketidakefektifan tersebut disebabkan oleh (a) muatan dalam regulasi belum sepenuhnya bisa operasional; (b) pelaksanaan pengawasan di lapangan terbatas; (c) peran masyarakat dalam pengawasan adanya pelanggaran terhadap tata ruang belum optimal; (d) fungsi koordinasi antar organisasi perangkat daerah dalam peran masing-masing belum maksimal dilakukan; dan (e) kondisi dan status PPNS yang belum kuat. Ketidakefektifan tersebut dapat di atasi dengan strategi kebijakan penertiban pemanfaatan ruang yang berupa penguatan regulasi, penguatan sumberdaya manusia, penataan kelembagaan, dan pengalokasian anggaran yang memadai.
\end{abstract}

Kata Kunci: Penegakan Hukum; Pemanfaatan Ruang; UUCK; Evaluasi; Strategi

[Title: Strengthening The Implementation of Law Enforcement in Space Utilization After Enactment of UndangUndang Cipta Kerja]. The current implementation of law enforcement in spatial utilization tends to stop at finding indications of violations of spatial utilization. The imposition of sanctions which are the result of the spatial planning audit is still rarely implemented. This shows that law enforcement in the spatial planning sector is still not optimal. On the other hand, new challenges emerge in the implementation of law enforcement in spatial use after the enactment of the Undang-Undang Cipta Kerja (UUCK) in 2020. This study aims to identify problems in the implementation of law enforcement in spatial utilization and then formulate strategies to strengthen the implementation of law enforcement in spatial utilization after the enactment of the UUCK. The research was conducted using a desk study method that prioritizes content analysis. Content analysis is carried out on regulations and one of the spatial audit reports. The data collected is in the form of data on indications of violations of space utilization from the results of the audit and the implementation of its follow-up. The results of the study indicate that the implementation of controlling the use of space is not effective. This ineffectiveness is caused by (a) the content in the regulation is not yet fully operational; (b) the implementation of supervision in the field is limited; (c) the role of the community in supervising the violation of spatial planning has not been optimal; (d) the coordination function between regional apparatus organizations in their respective roles has not been maximally carried out; and (e) the condition and status of PPNS are not yet strong. The results showed that there are problems that often arise in the implementation of law enforcement in spatial use so it requires a strategy for spatial use control policies in the form of strengthening regulations, strengthening human resources, institutional arrangements, and adequate budget allocation.

Keywords: Law Enforcement; Space Utilization; UUCK; Evaluation; Strategy 
Cara Mengutip: Sutaryono, Sutaryono., Nurrokhman, Arsan., \& Lestari, Novita Dian. (2021). Penguatan Pelaksanaan Penertiban Pemanfaatan Ruang Pasca Terbitnya Undang-Undang Cipta Kerja. Jurnal Pengembangan Kota. Vol 9 (2): 154-165. DOI: 10.14710/jpk.9.2.154-165

\section{PENDAHULUAN}

Dalam beberapa tahun terakhir, penataan ruang dipahami sebagai proses pengambilan keputusan atas penggunaan lahan dalam masyarakat, berdasarkan penilaian dan penyeimbangan atas tuntutan-tuntutan daya saing (Segura \& Pedregal, 2017). Jumlah dan aktivitas penduduk yang meningkat serta luas lahan yang terbatas berdampak pada adanya dinamika penggunaan lahan (Putra \& Pradoto, 2016). Persaingan penggunaan lahan mengarah pada terjadinya perubahan penggunaan lahan yang merupakan fenomena lazim perkotaan. Dalam hal ini, permasalahan yang terjadi adalah bahwa perubahan tersebut acapkali menyimpang dari rencana tata ruang yang telah ditetapkan sehingga menimbulkan dampak-dampak negatif (Kustiwan \& Anugrahani, 2015). Faktor-faktor yang mempengaruhi penyimpangan/tidak sejalannya implementasi dengan rencana tata ruang antara lain dikarenakan adanya tekanan pengembangan pasar, ketidakjelasan mekanisme kontrol, dan lemahnya penegakan hukum (Rosdiana, 2018). Penyimpangan tata ruang yang terjadi juga dipengaruhi oleh rendahnya pengetahuan masyarakat tentang rencana tata ruang dan kurangnya sosialisasi terkait rencana tata ruang tersebut (Eko \& Rahayu, 2012). Berdasarkan halhal tersebut, dapat dipahami bahwa pelanggaran penataan ruang disebabkan antara lain oleh (1) potensi konflik antar wilayah, (2) potensi konflik antar sektor, dan (3) potensi konflik antara pemerintah dan masyrakat (Jazuli, 2017).

Sebuah penelitian di Kabupaten Tanah Datar menyebutkan bahwa $43.7 \%$ pengembangan kawasan permukiman yang terdapat di kabupaten tersebut tidak sesuai dengan Rencana Tata Ruang Wilayah (RTRW) sehingga diperlukan kebijakan terkait konsistensi implementasi rencana tata ruang dan penegakan hukum dalam menyikapi adanya pelanggaran pemanfaatan ruang (Umar dkk., 2019). Penegakan hukum harus terus dilakukan untuk mengurangi dampak dari pelanggaran itu sendiri, sekaligus untuk memperlihatkan bahwa peraturan tidak hanya sebatas kebijakan dengan ketidaksesuaian implementasi (Sodikin, 2017).

Dalam pandangan umum, penegakan hukum diartikan sebagai tindakan penerapan instrumen hukum tertentu untuk melaksanakan sanksi hukum demi terjaminnya penataan pada ketentuan yang telah ditetapkan (Junef, 2021). Terdapat 5 (lima) faktor yang mempengaruhi penegakan hukum yakni: (1) faktor hukum itu sendiri (peraturan perundang-undangan), (2) faktor penegak hukum, (3) faktor sarana, (4) faktor masyarakat, dan (5) faktor kebudayaan (Soekanto, 2004). Apabila dikaitkan dengan faktor hukum itu sendiri, maka berdasarkan undang-undang penataan ruang, penegakan hukum administratif dalam konteks implementasi rencana tata ruang atas izin-izin yang dikeluarkan oleh pemerintah mencakup pengawasan dan penegakan sanksi (Dianto \& Cahyaningtyas, 2021). Oleh karena itu dapat dipahami bahwa lemahnya pengawasan dan penegakan sanksi (penertiban), menunjunjukkan lemahnya penegakan hukum. Lemahnya penegakan hukum atas pelanggaran penataan ruang memberi akibat pada masih terjadinya pelanggaran penataan ruang baik di pusat maupun di daerah (Jazuli, 2017).

Salah satu upaya untuk mengurai dan/atau mengungkap adanya pelanggaran penataan ruang adalah dengan melakukan audit tata ruang. Audit tata ruang merupakan serangkaian kegiatan pemeriksaan dan evaluasi terhadap data dan informasi spasial serta dokumen pendukung untuk mengevaluasi suatu laporan atau temuan yang diduga sebagai indikasi pelanggaran pemanfaatan ruang (Peraturan Menteri Agraria dan Tata

\section{ISSN 2337-7062 (c) 2021}

This is an open access article under the CC-BY-NC-ND license (http://creativecommons.org/licenses/by-nc-sa/4.0/). - lihat halaman depan (C) 2021

*Email sutaryono@stpn.ac.id

Diterima 8 April 2021, disetujui 30 November 2021 
Ruang/Kepala Badan Pertanahan Nasional Nomor 17 Tahun 2017 tentang Pedoman Audit Tata Ruang). Jika hasil audit tata ruang menghasilkan temuan adanya indikasi pelanggaran pemanfaatan ruang, maka hasil temuan tersebut kemudian ditindaklanjuti dengan agenda penertiban pemanfaatan ruang berupa pelaksanaan rekomendasi pengenaan sanksi, baik sanksi administratif atau sanksi pidana.

Permasalahan yang terjadi saat ini adalah adanya kecenderungan tidak dilaksanakannya rekomendasi pengenaan sanksi hasil audit tata ruang pasca ditemukannya indikasi pelanggaran pemanfaatan ruang. Hal tersebut antara lain disebabkan oleh faktor kualitas SDM, kualitas rencana tata ruang, dan kualitas penindakan yang masih kurang. Terkait kualitas SDM, petugas pengawas lapangan terbatas dan lemahnya koordinasi antar pemangku kepentingan. Terkait kualitas, kondisi RTRW yang perbedaannya terlalu jauh dengan kondisi eksisting yang berakibat pada lemahnya tindaklanjut hasil pengawasan ke arah penindakan (Pamungkas, 2020). Permasalahan tersebut semakin kompleks dengan ditetapkannya undang-undang cipta kerja (UUCK) di akhir tahun 2020. Di dalam UUCK, pengenaan sanksi mengalami pergeseran yang cukup signifikan yakni lebih mengedepankan pengenaan sanksi administratif dibandingkan dengan sanksi pidana. Hal tersebut dikuatirkan justru dapat mendorong terjadinya pelanggaran karena sanksi administratif kurang dapat menimbulkan efek jera.

Kecenderungan bahwa pelaksanaan penertiban pemanfaatan ruang hanya terhenti pada tahap penemuan adanya indikasi pelanggaran pemanfaatan ruang, memperlihatkan bahwa upaya penegakan hukum di bidang penataan ruang masih belum optimal. Penelitian ini bertujuan untuk mengevaluasi pelaksanaan penertiban ruang, untuk kemudian merumuskan strategi penguatan pelaksanaan penertiban pemanfaatan ruang, terlebih pasca ditetapkannya UUCK. Penelitian diharapkan dapat memberikan sumbangsih bagi penguatan pelaksanaan penertiban pemanfaatan ruang pasca ditetapkannya UUCK dalam rangka mewujudkan tertib tata ruang.

\section{METODE PENELITIAN}

Penelitian dilakukan dengan menggunakan metode desk study yang mengutamakan content analysis. Content analysis dilakukan terhadap regulasi, program dan kegiatan, serta data dan informasi. Content analysis merupakan analisis untuk mengkaji suatu teks atau data dengan objektif untuk mendapatkan gambaran dari suatu isi apa adanya, tanpa campur tangan peneliti. Metode ini menghilangkan bias, keberpihakan dan kecenderungan tertentu dari peneliti. Hasil analisis isi benar-benar mencerminkan isi dari suatu teks dan bukan akibat subjektifitas peneliti (Ahmad, 2018). Dalam konteks ini, pendekatan penelitian yang digunakan merupakan penelitian campuran.

Secara operasional, teknik analisis deskriptif digunakan untuk mengelaborasi kondisi kebijakan penertiban pemanfaatan ruang pada wilayah provinsi dan kabupaten/kota. Dalam hal ini data yang digunakan adalah hasil audit tata ruang pada sebuah kabupaten/kota, yang bersifat rahasia (Pasal 64 Permen ATR/KBPN 17/2017). Oleh karena itu dalam naskah disebutkan sebagai Kabupaten X.

Secara operasional, teknik analisis deskriptif digunakan untuk mengelaborasi kondisi kebijakan penertiban pemanfaatan ruang pada wilayah provinsi dan kabupaten/kota. Dalam hal ini data yang digunakan adalah hasil audit tata ruang pada sebuah kabupaten/kota, yang bersifat rahasia (Pasal 64 Permen ATR/KBPN 17/2017). Oleh karena itu dalam naskah disebutkan sebagai Kabupaten X.

Analisis komparatif digunakan untuk mencermati muatan dalam regilasi, baik sebelum UUCK maupun sesudah UUCK. Dalam hal ini komparasi dilakukan terhadap muatan yang ada dalam PP 15 Tahun 2010 (sebelum UUCK) dengan PP Nomor 21 Tahun 2021 (setelah UUCK).

Pendalaman terhadap kondisi implementasi kebijakan penertiban pemanfaatan ruang di atas digunakan untuk menemukenali berbagai permasalahan yang muncul dalam pelaksanaan kebijakan penertiban pemenfaatan ruang. Berdasarkan hasil tersebut dirumuskan alternatif penyelesaian masalah melalui perumusan 
kebijakan dan strategi kebijakan dan implementasi kebijakan penertiban pemanfaatan ruang.

\section{HASIL DAN PEMBAHASAN}

\subsection{Pelaksanaan Kebijakan Penertiban Pemanfaatan Ruang}

Pembiayaan kegiatan otoritas penegak hukum dalam rangka pengeluaran anggaran untuk penegakan undang-undang memiliki kekurangan dalam hal perencanaan alokasi dan pemanfaatan sumber keuangan untuk tujuan penegakan hukum (Bakhyt dkk., 2015). Sejalan dengan hal tersebut, dalam mengimplementasikan kebijakan penertiban pemanfaatan ruang, pemerintah pusat melalui Direktorat Penertiban Pemanfaatan Ruang mengalokasikan anggaran audit tata ruang di berbagai wilayah. Alokasi anggaran ini dilakukan untuk mengevaluasi suatu laporan atau temuan yang diduga sebagai indikasi pelanggaran di bidang penataan ruang. Namun demikian, dari sisi pemerintah daerah, informan yang dihubungi menyatakan bahwa pemerintah daerah yang bersangkutan belum mengalokasikan anggaran untuk kegiatan audit tata ruang.

Di samping itu, terdapat keterbatasan sumber daya manusia di daerah yang mempunyai kemampuan teknis dalam pelaksanaan audit tata ruang. Adanya kekurangan dalam hal faktor sumber daya manusia merupakan salah satu faktor yang memberi pengaruh terhadap penegakan hukum (Soekanto, 2004). Motivasi, kompetensi, mentalitas/personalitas, serta rasio kecukupan jumlah dari aparat memegang peran yang penting. Peraturan sebaik apapun apabila aparat penegaknya tidak memiliki motivasi yang baik, tidak memiliki kompetensi dalam pelaksanaan tugas lapangan, memiliki mentalitas/personalitas korupsi, dan secara rasio jumlah tidak mencukupi, maka penegakan hukum tidak akan berjalan seperti yang diharapkan. Keseluruhan hal tersebut menunjukkan bahwa agenda penertiban pemanfaatan ruang masih dianggap bukan sebagai prioritas.

Di sisi lain, data hasil audit tata ruang menunjukkan bahwa tipologi pelanggaran yang paling banyak terjadi adalah pemanfaatan ruang yang tidak sesuai dengan rencana tata ruang, pemanfaatan ruang yang tidak sesuai dengan izin yang diberikan, pemanfaatan ruang yang tidak sesuai dengan persyaratan izin yang diberikan, dan pemanfaatan ruang yang menutup akses terhadap kawasan yang dinyatakan oleh peraturan peundang-undangan sebagai milik umum. Data tersebut diperoleh melalui laporan audit tata ruang pada satu wilayah kabupaten, dimana ditemukan adanya 28 kegiatan yang terindikasi melanggar tata ruang dengan tipologi sebagaimana di atas berdasarkan laporan hasil audit Kabupaten X, 2019.

Terkait tipologi di atas, hal yang kerap terjadi adalah bahwa pelanggaran baru diketahui setelah bangunan yang melanggar selesai dibangun atau bahkan telah beroperasi, dan menimbulkan perubahan fungsi ruang/kerugian. Dalam hal ini, sanksi yang akan dikenakan kerap memunculkan resistensi dari pihak penerima sanksi. Menyikapi hal ini, kegiatan penertiban yang seringkali dilakukan adalah pemberian surat peringatan dan pemasangan plang. Namun demikian, walaupun pelaku pelanggaran tidak mengindahkannya, tahapan sanksi berikutnya tidak dilaksanakan. Penyebab utama dari hal tersebut adalah karena kegiatan penertiban dilakukan saat bangunan telah berdiri dan/atau kegiatan dengan fungsi ruang yang tidak sesuai peruntukan tersebut telah berlangsung. Hal tersebut juga menjadi salah satu penyebab rendahnya pengenaan sanksi pasca ditemukannya indikasi pelanggaran pemanfaatan ruang.

Data pada Direktorat Jenderal Pengendalian Pemanfaatan Ruang dan Penguasaan Tanah Kementerian Agraria dan Tata Ruang/Badan Pertanahan Nasional (ATR/BPN), menunjukkan bahwa audit tata ruang dalam kurun waktu 20152018 menemukan 6.621 lokasi yang terindikasi melanggar pemanfaatan ruang. Dari jumlah tersebut hanya sebagian kecil yang ditindaklanjuti. Berdasarkan interview dengan Direktur Penertiban Pemanfaatan Ruang Kementerian ATR/BPN (Januari 2022) diperoleh informasi bahwa: (a) ditemukan melalui audit dan belum ditindaklanjuti sejumlah 3.625 kasus; (b) ditemukan melalui audit dan ditindaklanjuti dengan fasilitasi penertiban sejumlah 558 kasus; dan (c) ditemukan melalui audit dan ditindaklanjuti dengan fasilitasi 
penertiban dan pengawasan, pengamatan, penelitian sejumlah 716 kasus.

Dalam konteks lokal (pemerintah daerah) kondisinya tidak berbeda dengan konteks nasional. Temuan indikasi pelanggaran pemanfaatan ruang yang ditindaklanjuti relatif rendah. Tabel 1 berikut merupakan satu contoh hasil audit pada Kabupaten X, dimana dari 28 temuan indikasi pelanggaran tata ruang, hanya 5 (lima) kasus yang ditindaklanjuti.

Tabel 1. Hasil Audit Tata Ruang Pada Kabupaten X

\begin{tabular}{|c|c|c|}
\hline No & $\begin{array}{l}\text { Lokasi Indikasi } \\
\text { Pelanggaran }\end{array}$ & Keterangan \\
\hline 1 & Lokasi 1 & Tidak ditindaklanjuti \\
\hline 2 & Lokasi 2 & Tidak ditindaklanjuti \\
\hline 3 & Lokasi 3 & Tidak ditindaklanjuti \\
\hline 4 & Lokasi 4 & Tidak ditindaklanjuti \\
\hline 5 & Lokasi 5 & Tidak ditindaklanjuti \\
\hline 6 & Lokasi 6 & Tidak ditindaklanjuti \\
\hline 7 & Lokasi 7 & Tidak ditindaklanjuti \\
\hline 8 & Lokasi 8 & Tidak ditindaklanjuti \\
\hline 9 & Lokasi 9 & Tidak ditindaklanjuti \\
\hline 10 & Lokasi 10 & Tidak ditindaklanjuti \\
\hline 11 & Lokasi 11 & Tidak ditindaklanjuti \\
\hline 12 & Lokasi 12 & Tidak ditindaklanjuti \\
\hline 13 & Lokasi 13 & Tidak ditindaklanjuti \\
\hline 14 & Lokasi 14 & Tidak ditindaklanjuti \\
\hline 15 & Lokasi 15 & Ditindaklanjuti \\
\hline 16 & Lokasi 16 & Tidak ditindaklanjuti \\
\hline 17 & Lokasi 17 & Tidak ditindaklanjuti \\
\hline 18 & Terminal & Tidak ditindaklanjuti \\
\hline 19 & Rumah Makan & Ditindaklanjuti \\
\hline 20 & Bangunan Pasar & Tidak ditindaklanjuti \\
\hline 21 & Kawasan Pelabuhan & Tidak ditindaklanjuti \\
\hline 22 & Bangunan Pesantren & Tidak ditindaklanjuti \\
\hline 23 & Perumahan 1 & Tidak ditindaklanjuti \\
\hline 24 & Perumahan 2 & Tidak ditindaklanjuti \\
\hline 25 & Usaha Peternakan & Tidak ditindaklanjuti \\
\hline 26 & Perumahan 3 & Ditindaklanjuti \\
\hline 27 & $\begin{array}{l}\text { Bangunan Wisata di } \\
\text { Pantai }\end{array}$ & Ditindaklanjuti \\
\hline 28 & $\begin{array}{l}\text { Bangunan Pertokoan } \\
\text { di Pantai }\end{array}$ & Ditindaklanjuti \\
\hline
\end{tabular}

Sumber : Hasil Audit pada Kabupaten X Tahun 2019

Hal yang menjadi ironi di beberapa daerah adalah bahwa indikasi pelanggaran tata ruang hasil kegiatan audit dijadikan sebagai bahan untuk menyesuaikan rencana tata ruang (pada saat revisi) dengan kondisi eksisting agar menjadi sesuai peruntukannya. Hal ini menunjukkan adanya potensi praktik 'pemutihan' pemanfaatan ruang yang tidak sesuai dengan rencana tata ruang.

\subsection{Permasalahan Pelaksanaan Kebijakan Penertiban Pemanfaatan Ruang}

Beberapa permasalahan dalam melaksanakan kebijakan penertiban di daerah dapat dibedakan dalam 2 (dua) kategori, yakni: (1) pada saat menindaklanjuti hasil dari kegiatan audit; dan (2) paska pelaksanaan penertiban. Kedua kategori permasalahan tersebut memiliki problematika masing-masing dan perlu dicarikan solusi pemecahan masalahnya.

Kategori pertama terkait dengan permasalahan saat akan melakukan penertiban sebagai langkah lanjutan setelah kegiatan audit tata ruang. Permasalahan yang sering muncul adalah:

1. Pelanggaran tata ruang yang ada seringkali kemudian digunakan sebagai dasar revisi tata ruang, sehingga saat akan dilakukan penindakan akan muncul keraguan, sebab pihak daerah sedang melakukan revisi rencana tata ruangnya dan melakukan "pemutihan" terhadap pelanggaran-pelanggaran yang terjadi dengan menyesuaikan rencana pola ruangnya dengan kondisi eksisting. Hal ini akan menimbulkan ketidakpastian dalam penertiban (pemberian sanksi). Karena saat ini memang melanggar namun dengan rencana penyesuaian rencana pola ruang dengan pemanfaatan ruang eksisting maka akan terjadi keragu-raguan dalam melakukan penindakan.

2. Pada beberapa daerah terjadi ketidaktegasan OPD pengampu tata ruang, dimana setelah ditemukan pelanggaran tata ruang dan akan dilakukan penindakan seringkali mencari alasan pembenar dengan melihat peraturan perundangan sektoral yang membenarkan situasi tersebut. Akibatnya perda tata ruang yang seharusnya menjadi acuan dalam menilai pelanggaran menjadi tersamarkan dengan aturan-aturan sektoral lainnya yang beberapa bertentangan dengan perda tata ruang tersebut. Padahal seharusnya sebelum menjadi perda tata ruang maka seharusnya telah terjadi harmonisasi dengan peraturan perundangan sektoral lainnya. Seringkali posisi personal di OPD yang mengampu penindakan menghadapi 
situasi dilematis terkait karier dan beberapa hal lainnya.

3. Kualitas perda tata ruang yang tidak standar, dimana di dalam arahan peraturan zonasi atau ketentuan peraturan zonasi masih ada pengaturan yang bersifat "abu-abu". Dalam hal ini, perda tata ruang yang standar yang secara prosedur dan substansi mengikuti Permen ATR/Kepala BPN Nomor 1 Tahun 2018 untuk RTRW Provinsi dan Kabupaten Kota dan Permen ATR/Kepala BPN Nomor 16 Tahun 2018 tentang RDTR dan PZ, yang saat ini keduanya sudah diganti dengan Permen ATR/Kepala BPN Nomor 11 Tahun 2021 tentang Tentang Tata Cara Penyusunan, Peninjauan Kembali, Revisi, dan Penerbitan Persetujuan Substansi Rencana Tata Ruang Wilayah Provinsi, Kabupaten, Kota, dan Rencana Detail Tata Ruang.

Sebagai contoh tidak standarnya perda tentang tata ruang, dimana di satu pasal disebutkan boleh dikembangkan menjadi sebuah pola ruang tidak boleh digunakan untuk penggunaan lahan lain, namun di pasal lainnya justru memperbolehkan percampuran penggunaan lahan. Ada juga aturan KLB (koefisien lantai bangunan) yang harus sekian persen, namun di pasal lain disebutkan boleh melebihi ketentuan KLB atas mendapat izin dari otoritas pengguna ruang udara setempat. Sehingga langkahlangkah penertiban menjadi sebuah keraguraguan.

Untuk kategori kedua terkait dengan permasalahan paska kegiatan penertiban di level awal. Dalam hal ini, kegiatan penertiban dibatasi pada ranah pengenaan sanksi administratif (PP Nomor 21 Pasal 188 Tahun 2021 tentang Penyelenggaraan Penataan Ruang (Peraturan Pemerintah Nomor 21 Pasal 188 Tahun 2021 tentang Penyelenggaraan Penataan Ruang)). Dalam teori hukum, tujuan dari sanksi administratif bukan untuk memberikan nestapa melainkan untuk mengembalikan ke kondisi semula (Junef, 2021). Adapun bentuk-bentuk dari sanksi administratif yakni berupa peringatan tertulis, denda administratif, penghentian sementara kegiatan, penghentian sementara pelayanan umum, penutupan lokasi, pencabutan KKPR, pembatalan KKPR, pembongkaran bangunan, dan/atau pemulihan fungsi ruang. Bentuk sanksi yang dikenakan diawali dengan pemberian peringatan tertulis (maksimal 3 kali). Apabila hal ini diabaikan, maka berlaku pengenaan bentuk sanksi berikutnya dan seterusnya sampai ke pengenaan bentuk sanksi berupa pemulihan fungsi ruang (Peraturan Pemerintah Nomor 21 Pasal 198 Tahun 2021)). Permasalahan yang sering muncul adalah:

1. Kegiatan penertiban terkesan seperti simbolis, dimana contohnya setelah pemberian surat peringatan sebanyak 3 kali kemudian pemasangan papan peringatan namun setelah lewat masa peringatan tetap tidak ada kegiatan penertiban lanjutan. Hal ini mengakibatkan kegiatan penertiban menjadi kurang wibawanya dan tidak menimbulkan efek jera.

2. Kurangnya sumberdaya manusia (SDM) yang melakukan penertiban. Hal ini menjadi masalah klasik bahwa di beberapa kabupaten/kota di Indonesia sangat sedikit PPNS penataan ruang. Bahkan di beberapa daerah tidak ada sama sekali PPNS penataan ruang. Sehingga untuk penindakan kasus pelanggaran penataan ruang yang terancam dengan sanksi pidana menjadi sulit dilaksanakan.

3. Penindakan yang kurang efektif dengan dampak yang ditimbulkan, dimana contohnya ada sebuah perusahaan tambang yang tidak berizin dan diberi surat peringatan untuk penghentian operasi dalam 14 hari, maka yang dilakukan oleh perusahaan adalah justru menggenjot produksi besar-besaran dalam 14 hari dan kemudian baru berhenti di hari ke 15, sehingga dampak kerusakan justru akan meningkat signifikan justru saat surat peringatan diberikan. Contoh lain adalah pengenaan denda yang terlalu kecil dibandingkan dampak kerusakan yang ditimbulkan dari kegiatan.

4. Permintaan pencabutan surat peringatan, pada beberapa kasus terjadi penggunaan kekuasaan dari otoritas setempat untuk meminta tim penertiban yang telah memberikan surat peringatan untuk mencabut kembali surat peringatan tersebut dengan alasan-alasan subyektif. Karena kedudukan yang lebih tinggi maka tim penertiban akhirnya terpaksa melakukan tindakan pencabutan. Sehingga wibawa penertiban tata ruang menjadi berkurang. 


\subsection{Efektifitas Implementasi Kebijakan Penertiban Pemanfaatan Ruang}

Kebijakan penertiban pemanfaatan ruang tidak dapat dilepaskan dari instrumen pengendalian pemanfaatan ruang. Sebelum ditetapkannya UUCK dan PPPPR Tahun 2021, pengendalian pemanfaatan ruang dilakukan melalui 3 instrumen yang bersifat pencegahan (peraturan zonasi, perizinan, dan insentif-disinsentif) dan 1 instrumen yang bersifat penanggulangan (pengenaan sanksi). Tiga instrumen yang bersifat pencegahan tersebut masih menyisakan sejumlah pekerjaan rumah yang harus segera ditangani, yakni:

1. Belum tersusunnya Peraturan Zonasi (PZ) secara tuntas. PZ merupakan bagian tak terpisahkan dari RDTR. Data dari Ditjend Tata Ruang Kementerian ATR/BPN (2019), baru terdapat 53 RDTR yang berhasil diperdakan dari total 2000-an RDTR untuk seluruh Indonesia. Data terkini pada portal Protaru Kementerian ATR/BPN, sudah terdapat 173 RDTR yang diperdakan;

2. Adanya paradigma bahwa izin merupakan pintu masuk bagi pemanfaatan ruang dan bukan sebagai instrumen pengendalian pemanfaatan ruang. Idealnya, izin dikeluarkan untuk mewujudkan rencana tata ruang yang telah digariskan dan bukan untuk mewadahi keinginan pemodal;

3. Ragam dan teknis pelaksanaan insentifdisinsentif yang belum terinci secara jelas dan lengkap, baik dalam bentuk NSPK, Perda, Perkada, maupun SK Kepala Daerah. Idealnya, masing-masing pemerintah daerah menyediakan peraturan terkait insentif disinsentif secara mandiri karena tiap-tiap daerah mempunyai karakteristik ruang dan kearifan lokal yang spesifik. Aturan insentifdisinsentif hendaknya melekat pada unsurunsur keunikan daerah tertentu.

Ketiga instrumen pengendalian yang berupa pencegahan ini merupakan alat-alat identifikasi di awal pelaksanaan penertiban pemanfaatan ruang. Instrumen peraturan zonasi merupakan ketentuan yang mengatur pemanfaatan ruang dan unsurunsur pengendalian yang disusun untuk setiap zona peruntukan (Undang-Undang Republik Indonesia Nomor 26 Tahun 2007 tentang Penataan Ruang)). Peraturan zonasi memuat ketentuan yang harus, boleh, dan tidak boleh dilakukan pada zona pemanfaatan ruang (Undang-Undang Republik Indonesia Nomor 26 Tahun 2007 tentang Penataan Ruang). Peraturan zonasi juga merupakan alat pengendali pemanfaatan lahan yang digunakan untuk mengkonservasi sumber daya lahan, membatasi eksternalitas negatif pembangunan kepadatan tinggi, dan mencapai manfaat yang besar dari kegiatan konservasi lahan di dalam suatu blok yang besar (Liu \& Lynch, 2011). Peraturan zonasi berfungsi sebagai petunjuk teknis bagi pemanfaatan ruang dan pengendalian pemanfaatan ruang (Kautsary, 2018). Dengan demikian, peran peraturan zonasi sebagai alat identifikasi awal pelaksanaan penertiban memberikan rujukan atas persyaratan dan/atau ketentuan kegiatan di dalam masing-masing zonanya.

Di sisi lain, instrumen izin memiliki peran penting bagi penataan ruang melalui izin pemanfaatan ruang (Hastuti, 2020). Izin merupakan alat pemerintah yang bertujuan untuk mengendalikan perilaku masyarakat (Mardhani, 2019). Lebih lanjut, terkait izin pemanfaatan ruang berdasarkan UU Penataan Ruang, kegiatan yang memiliki peluang mengakibatkan gangguan pada prinsipnya tidak diperbolehkan kecuali dengan izin. Dalam hal ini, perizinan tersebut adalah izin kegiatan, izin pertanahan, dan izin perencanaan \& bangunan (Rosdiana, 2018). Dengan demikian, instrumen perizinan sebagai alat identifikasi awal kegiatan penertiban memberikan justifikasi atas keseuaian kegiatan tanah, rencana, dan bangunan dengan rencana dan standar yang telah ditetapkan.

Insentif dan disinsentif merupakan konsep dari suatu sistem yang bertujuan untuk mengontrol dan mengatur penggunaan lahan dan pengelolaan ruang (Boka, 2016). Pemberian insentif ditujukan sebagai bentuk penggantian atas pelaksanaan kegiatan yang sesuai dengan rencana tata ruang. Disinsentif ditujukan sebagai upaya pencegahan, pembatasan, dan/atau pengurangan pelaksanaan kegiatan yang tidak sesuai dengan rencana tata ruang (Artaya, 2016). Dengan demikian, Instrumen insentif dan disinsentif berperan sebagai alat untuk mengidentifikasi kawasan yang didorong atau dibatasi pengembangannya, sehingga dapat mempermudah menemukenali ada tidaknya pelanggaran pemanfaatan ruang pada kawasan- 
kawasan dimaksud. Beberapa 'pekerjaan rumah' yang belum tuntas atas ketiga instrumen tersebut (peraturan zonasi, perizinan, dan insentifdisinsentif), menyebabkan kurang efektifnya pelaksanaan penertiban pemanfaatan ruang.

Instrumen pengendalian pemanfaatan ruang keempat yang bersifat penanggulangan (pengenaan sanksi) masih memiliki keterbatasan dalam implementasinya. Ketidakefektifan implementasi tersebut antara lain disebabkan karena pelaksanaan penyidikan yang masih dilakukan oleh organ internal pemerintah (PPNS), proses pentipologian indikasi pelanggaran pemanfaatan ruang, wilayah kewenangan tim audit tata ruang, dan batas waktu pelaksanaan tindak lanjut hasil audit tata ruang.

Hal tersebut di atas sedikit banyak dipengaruhi oleh adanya 2 (dua) produk kebijakan penertiban pemanfaatan ruang yakni Peraturan Menteri Agraria dan Tata Ruang/Kepala BPN Nomor 3 Tahun 2017 tentang Penyidik Pegawai Negeri Sipil Penataan Ruang dan Peraturan Menteri Agraria dan Tata Ruang/Kepala BPN Nomor 17 Tahun 2017 tentang Pedoman Audit Tata Ruang.

Dalam membedah materi muatan Permen tentang PPNS, setidaknya terdapat hal penting yang perlu mendapat perhatian dalam rangka efektifitas kinerja PPNS Penataan Ruang yakni terkait perlindungan dan pencetakan PPNS Penataan Ruang.

Perlindungan terhadap pemberhentian dari jabatan diperlukan mengingat pada dasarnya PPNS Penataan Ruang adalah Pegawai Negeri Sipil (PNS) yang diangkat menjadi PPNS penata ruang oleh Menteri Hukum dan HAM untuk melakukan penanganan tindak pidana bidang penataan ruang. Dalam Pasal 20 disebutkan bahwa PPNS Penataan Ruang dapat diberhentikan dari jabatannya, salah satunya apabila tidak bertugas lagi di teknis operasional bidang penata ruang atau hukum. Sebagai PNS yang secara hirarki struktural berada di bawah Kepala Daerah, PPNS Penataan Ruang di daerah sangat mungkin mengalami mutasi ke luar bidang teknis operasional penataan ruang apabila Kepala Daerah memutuskan untuk melakukan mutasi. Dengan mutasi tersebut, maka secara otomatis jabatan sebagai PPNS Penataan Ruang akan terhenti. Apabila yang bersangkutan sedang melaksanakan tugas penyidikan, maka yang bersangkutan tidak dapat lagi terlibat dalam proses penyidikan.

Hal terkait mutasi PPNS telah ditindaklanjuti dalam Permen ATR/Kepala BPN Nomor 23 Tahun 2020 tentang perubahan atas Permen ATR/Kepala BPN Nomor 3 Tahun 2017 tentang PPNS Penataan Ruang. Muatan Permen tersebut mengatur bahwa mutasi hanya boleh dilakukan setelah 5 tahun. Namun demikian, selama PPNS masih merupakan organ pemerintah dan pembentukannya masih atas persetujuan pemerintah, maka adanya pembatasan mutasi masih kurang efektif.

Terkait pencetakan PPNS, dapat dikatakan bahwa pencetakan PPNS masih merupakan salah satu penghambat efektifitas pelaksanaan penyidikan. Hal ini karena target jumlah PPNS dan realisasinya masih jauh dari harapan. Realita memperlihatkan adanya kesulitan mendapatkan PNS untuk dididik menjadi PPNS penataan ruang. Hal ini masih belum terjawab dalam revisi permen PPNS. Durasi waktu diklat PPNS penataan ruang yang cukup lama dan gambaran tugas PPNS nantinya, membuat daerah enggan untuk mengirimkan kandidat untuk dididik menjadi PPNS penataan ruang.

Di dalam membedah materi muatan permen tentang audit tata ruang perlu kiranya melihat pada efektifitas pelaksanaan tindak lanjut hasil audit. Setidaknya terdapat 3 (tiga) poin yang perlu dibahas lebih lanjut dalam muatan permen tentang pedoman audit tata ruang. Hal yang pertama berkaitan dengan tipologi indikasi pelanggaran di bidang penataan ruang, hal kedua berkaitan dengan wilayah kewenangan tim audit tata ruang, dan hal yang ketiga adalah batas waktu pelaksanaan tindak lanjut hasil audit. Terkait tipologi pelanggaran, hal ini bukanlah sesuatu yang baru. Di Israel, amandemen legislatif memungkinkan otoritas perencana untuk menetapkan prioritas penegakan peraturan dan untuk membedakan pelanggaran kecil dan besar (Calor \& Alterman, 2017). Terkait kewenangan wilayah dan batas waktu pelaksanaan hasil audit, substansi Pasal 189 dan 194 PP Nomor 21 Tahun 2021 tentang Penyelenggaraan Penataan Ruang telah memberi ruang bagi perincian pengaturan ke 
depannya. Secara garis besar, ketiga hal tersebut dijelaskan sebagai berikut:

1. Tipologi indikasi pelanggaran bidang penataan ruang hendaknya tidak hanya ditentukan setelah melalui tahap pelaksanaan audit tata ruang, tetapi juga sebelum pelaksanaan audit. Hal tersebut mengingat bahwa input bagi dilaksanakannya audit salah satunya berasal dari pelaporan masyarakat. Dalam hal ini, masyarakat merupakan suatu entitas dengan tingkat pemahaman bidang tata ruang yang beragam dan hal tersebut berimplikasi pada beragamnya kasus-kasus pelanggaran yang dilaporkan (kasus ringan, sederhana, dan berat). Pedoman hendaknya memuat adanya mekanisme pentipologian awal indikasi pelanggaran yang berasal dari laporan-laporan masyarakat. Laporan-laporan yang masuk perlu disaring terlebih dahulu, untuk kemudian dilakukan pemeringkatan penanganan kasus yang dilengkapi dengan informasi terkait pihakpihak yang berwenang menangani pelaksanaan audit, pihak-pihak yang berpotensi untuk diperiksa, serta pihak-pihak yang memiliki kompetensi untuk memberikan bantuan dalam pelaksanaan audit. Dengan demikian, efektifitas tindak lanjut hasil audit sedari awal sudah dapat terpetakan, demikian juga kendala-kendala yang akan dihadapi sehingga langkah-langkah antisipasi pun dapat diskenariokan di awal pelaksanaan audit.

2. Permintaan pelaksanaan audit tata ruang di luar wilayah kewenangan hendaknya tidak hanya berlaku atas permintaan daerah ke pusat, tetapi juga dari pusat ke daerah. Hal ini mengingat tipologi kasus pelanggaran tata ruang sangat beragam (ringan, sedang, berat) sehingga sangat dimungkinkan terdapat kasus ringan yang terjadi di wilayah yang menjadi kewenangan pusat sehingga akan lebih efektif jika audit dilaksanakan oleh pemerintah daerah.

3. Muatan pedoman belum mengatur tentang batas waktu pelaksanaan tindak lanjut hasil audit pasca laporan hasil audit disampaikan. Jangka waktu yang diatur di dalam pedoman terbatas pada jangka waktu pelaksanaan audit tata ruang. Ketiadaan pengaturan terkait jangka waktu pelaksanaan tindak lanjut hasil audit pasca penyampaian laporan audit tata ruang membuat pelaksanaan pengenaan sanksi dan/atau penyidikan oleh PPNS penataan ruang (bila dinilai terdapat indikasi pelanggaran yang masuk ke dalam unsur pidana penataan ruang), menjadi tidak berkesudahan dan sangat bergantung pada political will dari pihak-pihak yang berwenang melaksanakan tindak lanjut tersebut. Oleh karena itu, agar penertiban pemanfaatan ruang dapat berjalan lebih efektif, skema penertiban pemanfaatan ruang sebagaimana Gambar 1 dapat diterapkan.

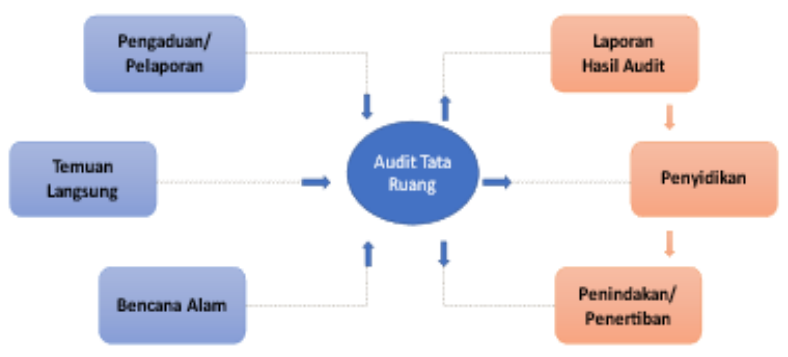

Gambar 1. Skema Penertiban Pemanfaatan Ruang Sumber: Permen ATR/KBPN 17/2017 \& Modifikasi

3.4. UUCK dan Implementasi Penertiban Pemanfaatan Ruang

Sebelum UUCK penyelenggaraan penataan ruang diatur melalui PP Nomor 15 Tahun 2010. Berkenaan dengan pengendalian pemanfaatan ruang, terdapat 4 (empat) instrumen, yakni: (1) pengaturan zonasi; (2) perizinan; (3) pemberian insentif dan disinsentif; dan (4) pengenaan sanksi. Berkenaan dengan sanksi, dalam regulasi ini terdapat ancaman sanksi administratif dan sanksi pidana.

Sesudah terbit UUCK penyelenggaraan penataan ruang diatur melalui PP 21 Tahun 2021. Dalam PP kegiatan pengendalian dilaksanakan melalui: (1) penilaian pelaksanaan kesesuaian kegiatan pemanfaatan ruang dan pernyataan mandiri pelaku UMK; (2) penilaian perwujudan RTR; (3) pemberian insentif dan disinsentif; (4) pengenaan sanksi; dan (5) penyelesaian sengketa Penataan Ruang. Instrumen pengendalian berupa perizinan dan peraturan zonasi diubah menjadi kesesuaian kegiatan pemanfaatan ruang (KKPR). Dalam regulasi ini tidak ada lagi ancaman sanksi pidana.

Tantangan di dalam pelaksanaan pengendalian dan penertiban pemanfaatan ruang pasca ditetapkannya UUCK akan semakin bertambah karena akan berhadapan dengan adanya persoalan 
yang mungkin timbul akibat persetujuan KKPR yang diproses tanpa adanya rencana detail tata ruang (RDTR).

Berdasarkan data pada portal Protaru Kementerian ATR/BPN, saat ini baru terdapat 173 RDTR yang diperdakan, sehingga dapat dikatakan sebagian besar pemerintah daerah belum memiliki RDTR. Banyaknya pemerintah daerah yang belum menyediakan RDTR diprediksi akan membuat tingkat permohonan persetujuan KKPR ke Pemerintah Pusat sangat tinggi. Di sisi lain, persetujuan KKPR yang diberikan nantinya, dimungkinkan memiliki tingkat ketepatan lokasi yang rendah karena umumnya peta RTRWN, RTR Pulau/Kepulauan, RTR KSN, dan/atau RTRW Provinsi/Kabupaten/Kota merupakan peta berskala kecil. Tumpang tindih lokasi di dalam persetujuan KKPR sangat mungkin akan terjadi.

Persoalan akan menjadi lebih berat lagi karena instrumen "perizinan" digantikan dengan "kesesuaian" yang memungkinkan lebih banyak celah untuk dilakukannya diskresi oleh aparatur sipil negara (ASN). Diskresi tanpa batasan jelas dan pemahaman yang sama tentang rencana tata ruang merupakan potensi bagi terjadinya pelanggaran pemanfaatan ruang.

Persoalan berikutnya adalah adanya pergeseran dalam hal pengenaan sanksi, dimana pasca UUCK sanksi pidana ditiadakan dan sanksi administratif yang mendapatkan prioritas. Dalam hal ini, pemberian sanksi administratif akan menghilangkan efek jera bagi para pelanggar. Namun demikian, dalam regulasi ini dasar dalam pengenaan sanksi lebih jelas, yakni berupa: (a) hasil penilaian pelaksanaan ketentuan KKPR; (b) hasil pengawasan penataan ruang; (c) hasil audit tata ruang; dan/atau (d) pengaduan pelanggaran pemanfaatan ruang.

Berkenaan dengan beberapa hal di atas, maka perlu dirumuskan strategi baru yang mampu mengatasi ketidakefektifan pengendalian dan penertiban pemanfaatan ruang selama ini. Strategi tersebut sangat memungkinkan untuk diwujudkan berdasarkan regulasi pasca UUCK, yang meliputi strategi penguatan regulasi, sumberdaya manusia, dan kelembagaan serta pengalokasian anggaran secara memadai.

\section{KESIMPULAN}

Faktor Penyebab Ketidakefektifan Pelaksanaan Penertiban Pemanfaatan Ruang

Berdasarkan analisis dan evaluasi pelaksanaan penertiban pemanfaatan ruang, maka faktor-faktor yang menjadi penyebab ketidakefektifan pelaksanaan penertiban pemanfaatan ruang adalah sebagai berikut:

1. Kepastian hukum yang tertuang dalam pasalpasal peraturan daerah secara substansi belum operasional;

2. Pengawasan bangunan dan pemanfaatan ruang di lapangan terbatas;

3. Peran masyarakat dalam mengadu bila terjadi pelanggaran izin dan tata ruang belum optimal;

4. Fungsi koordinasi antar organisasi perangkat daerah dalam peran masing-masing belum maksimal dilakukan;

5. PPNS tata ruang terbatas dan stagnant dalam menjalankan fungsinya, mengingat kedudukan kepegawaian PPNS pada posisi yang rentan.

Stategi Penguatan Pelaksanaan Penertiban Pemanfaatan Ruang

Berdasarkan analisis dan evaluasi pelaksanaan penertiban pemanfaatan ruang, maka strategi penguatan pelaksanaan penertiban pemanfaatan ruang perlu diarahkan pada:

1. Regulasi

- Diperlukan regulasi pada level pusat dan daerah terkait pedoman teknis penertiban pelanggaran pemanfaatan ruang;

- Diperlukan regulasi yang menjembatani peralihan pengenaan sanksi administratif ke sanksi pidana untuk menimbulkan efek jera dan menghindari tindakan 'pemutihan' atas pelanggaran pemanfaatan ruang yang terjadi.

- Diperlukan regulasi yang merinci tata cara pengambil alihan kewenangan pengenaan sanksi administratif oleh Gubernur dan Menteri.

2. Sumber Daya Manusia

- PPNS Penataan Ruang hendaknya tidak diposisikan sebagai subordinat dari kepala daerah melainkan menjadi organ 
pemerintah pusat yang ditugaskan di daerah;

- Kemampuan teknis SDM pemerintah di bidang penataan ruang hendaknya didukung dengan kepekaan moral sehingga menjadi filter dalam menentukan tindakan diskresi yang diambil.

3. Kelembagaan

- Dalam rangka memperkuat kinerja PPNS Penataan Ruang, fungsi penataan ruang (pengaturan, pembinaan, pelaksanaan dan pengawasan) dapat dimasukkan pada organ pemerintah pusat yang terdapat di daerah, yakni pada kantor wilayah BPN;

4. Pembiayaan

- Diperlukan pengalokasian anggaran yang memadai pada APBD untuk pelaksanaan kegiatan penertiban pemanfaatan ruang. Namun demikian, hal ini memerlukan political will dari kepala daerah untuk menempatkan agenda penertiban pemanfaatan ruang sebagai agenda prioritas daerah.

\section{UCAPAN TERIMA KASIH}

Tulisan ini dihasilkan dari penelitian yang didanai dari anggaran Pusat Pengembangan dan Standarisasi Kebijakan Agraria, Tata Ruang dan Pertanahan (PPSK-ATP) Kementerian ATR/BPN. Peneliti mengucapkan terimakasih kepada Kepala PPSK-ATP Kementerian ATR/BPN beserta seluruh jajarannya, Direktur dan Staf pada Direktorat Penertiban Pemanfaatan Ruang Kementerian ATR/BPN yang berkenan memberikan kesempatan untuk melaksanakan penelitian, berbagi data dan informasi serta dukungan dalam penyelesaian seluruh tahapan penelitian. Terimakasih disampaikan kepada J. Hamidin, M.Sc sebagai tengah ahli yang telah mendampingi selama proses penelitian.

\section{DAFTAR PUSTAKA}

Ahmad, J. (2018). Desain Penelitian Analisis Isi (Content Analysis). Research Gate, 5(9), 120.

Artaya, A. (2016). Kewenangan Pemerintah Kabupaten Badung Dalam Pengendalian Perizinan Pembangunan Sarana Akomodasi
Pariwisata. Jurnal Magister Hukum Udayana (Udayana Master Law Journal), 5(3), 543-558. Doi: https://doi.org/ 10.24843/JMHU.2016.v05.i03.p10

Bakhyt, M. N., Aiman, K. K., \& Alexey, V. B. (2015). The Price and Efficiency of the Law Enforcement in the Republic of Kazakhstan. The Social Sciences (Pakistan), 10(7), 1704-1711. Doi: https://doi.org/ 10.3923/sscience.2015.1704.1711

Boka, R. Y. (2016). The Evaluation of IncentiveDisincentive System in Tourism Development: A Case Study of Lake Linow development, Tomohon, North Sulawesi. Journal of Indonesian Tourism and Development Studies, 4(2), 49-56. Doi: https://doi.org/10.21776/ub.jitode.2016.0 04.02.01

Calor, I., \& Alterman, R. (2017). When enforcement fails: Comparative analysis of the legal and planning responses to non-compliant development in two advanced-economy countries. International Journal of Law in the Built Environment, 9(3), 207-239. Doi: https://doi.org/10.1108/IJLBE-06-20170021

Dianto, R., \& Cahyaningtyas, I. (2021). Administrative Law Enforcement against Urban Spatial Planning Based onthe Spatial Planning Law. International Journal of Social Science and Human Research, 04(05), 1174-1179. Doi: https://doi.org/ 10.47191/ijsshr/v4-i5-36

Eko, T., \& Rahayu, S. (2012). Perubahan Penggunaan Lahan dan Kesesuaiannya Terhadap RDTR di Wilayah Peri-Urban Studi Kasus: Kecamatan Mlati. Jurnal Pembangunan Wilayah dan Kota, 8(4), 330-340. Doi: https://doi.org/10.14710 /pwk.v8i4.6487

Hastuti, S. D. (2020). Pengendalian Pemanfaatan Ruang Melalui Izin Lokasi Dalam Rangka Perolehan Tanah Yang Diperlukan Usaha. Jurist-Diction, 3(3), 1099-1122. Doi: https://doi.org/10.20473/jd.v3i3.18640

Jazuli, A. (2017). Penegakan Hukum Penataan Ruang dalam Rangka Mewujudkan Pembangunan Berkelanjutan. Jurnal Rechts Vinding: Media Pembinaan Hukum Nasional, 6(2), 263-282. Doi: https:// doi.org/10.33331/rechtsvinding.v6i2.156 
Junef, M. (2021). Penegakkan Hukum Dalam Rangka Penataan Ruang Guna Mewujudkan Pembangunan Berkelanjutan. Jurnal Penelitian Hukum, 17(4), 373-390. Doi: https://doi.org/10.30641/dejure.2017 .V17.373-390

Kautsary, J. (2018). Perencanaan Peraturan Zonasi di Kawasan Konservasi (Studi Kasus Pecinan Semarang). Jurnal Planologi, 15(2), 216-229. Doi: https://doi.org/10.30659/ jpsa.v15i2.3526

Kustiwan, I., \& Anugrahani, M. (2015). Perubahan Pemanfaatan Lahan Perumahan ke Perkantoran: Implikasinya Terhadap Pengendalian Pemanfaatan Ruang Kota (Studi Kasus: Wlayah Pengembangan Cibeunying, Kota Bandung). Jurnal Perencanaan Wilayah dan Kota, 11(1), 8798.

Liu, X., \& Lynch, L. (2011). Do Zoning Regulations Rob Rural Landowners' Equity? Environmental Economics eJournal, 93(1). Doi: https://doi.org/10.1093/ajae/aaq164

Mardhani, Y. (2019). Eksistensi Izin Gangguan sebagai Instrumen Hukum Pengendalian Kegiatan USAha. Jurnal Hukum Magnum Opus, 2(1), 276594. Doi: https://doi.org/ 10.30996/jhmo.v2i2.2179

Pamungkas. (2020). Penegakan Sanksi dan Pengendalian Pemanfaatan Ruang di Kota Yogyakarta Materi Seminar Penelitian Penertiban Pemanfaatan Ruang Pada Wilayah Provinsi, Kabupaten dan Kota, Kementerian Agraria dan Tata Ruang/BPN, Kamis 10 Desember 2020.

Peraturan Menteri Agraria dan Tata Ruang/Kepala Badan Pertanahan Nasional Nomor 17 Tahun 2017 tentang Pedoman Audit Tata Ruang.

Peraturan Pemerintah Nomor 21 Pasal 188 Tahun 2021 tentang Penyelenggaraan Penataan Ruang.

Peraturan Pemerintah Nomor 21 Pasal 198 Tahun 2021.

Putra, D. R., \& Pradoto, W. (2016). Pola dan Faktor Perkembangan Pemanfaatan Lahan di Kecamatan Maranggen, Kabupaten Demak. Jurnal Pengembangan Kota, 4(1), 66-74. Doi: http://dx.doi.org/10.14710/ jpk.4.1.66-74
Rosdiana, Y. (2018). Analisis Yuridis Penyelenggaraan Izin Pemanfaatan Ruang (Study Pada Penyusunan Peraturan Daerah Tentang Izin Pemanfaatan Ruang Kabupaten Labuhan batu). De Lega Lata: Jurnal Ilmu Hukum, 3(1), 81-95. Doi: https://doi.org/10.30596/dll.v3i1.3149

Segura, S., \& Pedregal, B. (2017). Monitoring and Evaluation Framework for Spatial Plans: A Spanish Case Study. Sustainability, 9(10), 1706. Doi: https://doi.org/10.3390/ su9101706

Sodikin, S. (2017). Eksistensi Penyidik Pegawai Negeri Sipil (PPNS) Dalam Penegakan Hukum Terhadap Pelanggaran Tata Ruang. Jurnal Rechts Vinding: Media Pembinaan Hukum Nasional, 6(2), 283-300. Doi: https://doi.org/10.33331/rechtsvinding.v6i 2.169

Soekanto, S. (2004). Faktor-Faktor yang Mempengaruhi Penegakan Hukum. Jakarta: PT Raja Grafindo Persada.

Umar, I., Dewata, I., \& Barlian, E. (2019). Konsistensi Rencana Tata Ruang Permukiman dan Arahan Kebijakan Pembangunan di Kabupaten Tanah Datar, Provinsi Sumatera Barat. Journal of Natural Resources and Environmental Management, 9(2), 277-286. Doi: https://doi.org/10.29244/jpsl.9.2.276-287

Undang-Undang Republik Indonesia Nomor 26 Tahun 2007 tentang Penataan Ruang. 